\title{
The Analysis of Farmland Price Evaluation in Mortgage Financing from Shadow Price Perspective
}

\author{
Kai Hou* \\ College of Agricultural Economics and Management, Shanxi Agricultural University, Taiyuan 030031, China. \\ *Corresponding author. Email: 2419719067@qq.com
}

\begin{abstract}
Research objective: to determine appropriate value of the mortgaged property of farmland management right as a scientific benchmark prices. Research method: using statistical yearbook data of Sichuan province in 2013, based on the Cobb - Douglas production function to determine the shadow price of farmland. Research results: the shadow price of farmland in Sichuan province was 43508.238 Yuan $/ \mathrm{hm} 2$, as collateral valuation reference prices. Research conclusion: to use the farmland shadow price as a reference to estimate the mortgaged property, can increase bank margins and increase the availability of funds for peasant household, is conducive to the development of farmland finance.
\end{abstract}

Keywords: Farmland finance, Evaluate of the collateral, Shadow price.

\section{INTRODUCTION}

With the outbreak of COVID-19 and locust outbreaks in some countries in 2020 , food security has been highlighted. At the same time, there was a massive peasant movement in India, with hundreds of thousands of farmers storming the capital, and in Peru, farmers and agricultural workers staged large demonstrations and blocked key roads for negotiations with the government. For China, it is vital to ensure food security, safeguard the interests of its farmers, ensure rural stability, consolidate its gains in poverty alleviation, keep its rice bowl in its own hands (in President Xi Jinping's words), and provide humanitarian assistance to the rest of the world. To promote sustained improvement of agricultural productivity, we need to give full play to the basic role of the market in resource allocation, especially the rural land market. To perfect the rural land market and make the agricultural land price reflect reasonably in accordance with its resource scarcity, is a powerful guarantee to protect farmers' interests and promote the moderate-scale operation of agriculture. Sichuan Province is a populous province in China, and also a major agricultural province. In recent years, the reform of rural property rights in Sichuan Province has taken the lead in the state, and the agricultural operation have been advancing steadily toward the direction of modernization and moderate scale operation. Therefore, studying the price of farmland in the process of land property rights reform in Sichuan Province, make the farmland mortgage financing at a reasonable price level, through improvement of the farmland market to develop farmland finance, to awaken the rural sleeping assets, Introducing its scarce capital elements to the countryside, to ensure the smooth implementation of rural revitalization strategy, it has representative and typical significance.

China's rural land system is different from other countries which implemented private land ownership system, in those private land ownership system countries, peasant household can mortgage, guarantee, buying and selling their farmland. China's rural land is collectively owned, and for a long time in the past Chinese peasant household could not use their farmland for collateral. But things changed after the president $\mathrm{Xi}$ Jinping took office, in the third plenary session of the 18th CPC central committee in 2013, it was put forward in the conference report "To give peasants the right to occupy, use, gains, transfer their contracted farm land and mortgage or guarantee their farmland management right". The permission of farmland management right to mortgage was take place in the context of institutional change which was called "Three kinds of rights Separation".

Han changfu(2016), China's agriculture minister, explained that the "Three kinds of rights Separation" system refers to the separation between the collective 
ownership of rural land, farmland contract right of peasant household, and farmland management right. At the beginning of the Chinese economic reform in 1980s, the household contract responsibility system was implemented, rural collectivity had the ownership of rural land, peasant households had contracted management right of farmland, which was actually "Two kinds of rights Separation". Now conform to the wishes of peasants' to reserves the right of contracted land, and transfer farmland management right, divide the contracted management right of farmland to contracted right and management right, the farmland ownership still belong to rural collectivity, contracted right belong to peasant household, management right belong to farmland management entity (the original contracted peasant household or other agricultural management entities), to form the pattern of "Three kinds of rights Separation", the bundle of property rights be divided into ownership, contracted right and management right. It is another major innovation of rural reform in China to divide the land contracted management right into the contracted right and the right of management. "Three kinds of rights Separation" is a practical exploration to deepen the reform of rural land system.

Huang $\mathrm{Na}$ (2015) thought, the bundle of property rights be divided to contracted right and management right, make it have a supporting point to mortgage the farmland management right, and it become possible for the farmland capitalization, expand the property rights of peasant households, and it is conducive to increasing agricultural funds.

At present, in the practice of farmland finance, lack the authority of farmland value evaluation department, and impeccable farmland evaluation system .when farmland mortgage loan were issued, the determination of farmland value were perhaps simply based on the negotiation of both parties, perhaps even though there may be some appraisal agency in some places, but lack of the rigorous scientific evaluation basis, and professional assessment personnel. In some places, ascertain the farmland value just according to the rent of farmland and it's crops value. Subjective judgment play a big part in the assessment process, with it's subjective randomness. lack of the reference for independent value assessment, The value of farmland evaluated is often lower than it should be, the corresponding issuing loans is low at the same time, is not conducive to fully protect the interests of peasants, and unfavorable for banks and other financial institutions to carry out this business. The development of the farmland finance should be build on the basis of reasonable assessment of the value of farmland. Therefore, it is necessary to explore scientific, rigorous and fair farmland value evaluation method.

\section{THEORETICAL ANALYSIS}

People in solving the problem of optimal resource allocation used the linear programming method, found that the solution is a set of prices, and under this prices, resources could be optimally allocated, so it was called the optimal price, also known as shadow price. The shadow price is the intrinsic or real value of the production factor (or product) in the sense of equilibrium price, shadow prices reflect resources whether got reasonable allocation. In reality, due to the effect of various factors, the actual market prices sometimes deviated from the shadow price, so the shadow price can be used to measure the deviation degree that market price different from market value. shadow price calculated by optimization method, equivalent to the shadow price under the completely competitive market. To sum up, shadow price is the intrinsic value of resources expressed in the equilibrium sense, and the market price may deviate from it.

On the analysis of the macro economy, the market price is endogenous variables in the analysis system, according to the law of value, if there is a big deviation between market price and market value, it may lead to distortion of the resources allocation, and the waste of social resources, so it is necessary to know which factors price deviated from the value, how big is the degree of deviation, and on this basis, to correct it.

Macroeconomic analysis of farmland shadow price has an important meaning for farmland finance, the deviation between actual price and shadow price of farmland, can reflect the farmland price is overvalued or undervalued. At the same time, as the shadow price is the equilibrium price under the condition of optimal resources allocation, can from the deviation degree of actual farmland price to shadow price to judge whether resources get optimal allocation, whether the market fully developed. More importantly, the farmland as collateral in farmland finance practice, it is a fundamental issue how to assess the farmland value or by what standard to do so. To calculate the shadow price of farmland, is crux in the analysis of the problems of farmland finance, and plays an important role in farmland finance development.

\section{THE EMPIRICAL ANALYSIS}

This study use the agricultural output and production factors of 21 cities of Sichuan province in 2013 making regression, in order to get the production function. Adopted the $\mathrm{CD}$ production function form which was widely used, namely, Cobb-Douglas function form $\mathrm{Y}=\mathrm{AL}^{\alpha} \mathrm{K}^{\beta}$. According to the purpose of this research and the reference studies of other scholars, choose four variables as factor inputs, the $X_{1}$ is agricultural acreage at the end of the year, $X_{2}$ as agricultural labor force, the $\mathrm{X}_{3}$ for agricultural machinery total power, $\mathrm{X}_{4}$ for 
fertilizer usage amount. The dependent variable $\mathrm{Y}$ is yearbook of Sichuan province. agricultural output. Data was got from the statistical

Table 1. Agricultural output and input in 21 cities of Sichuan province

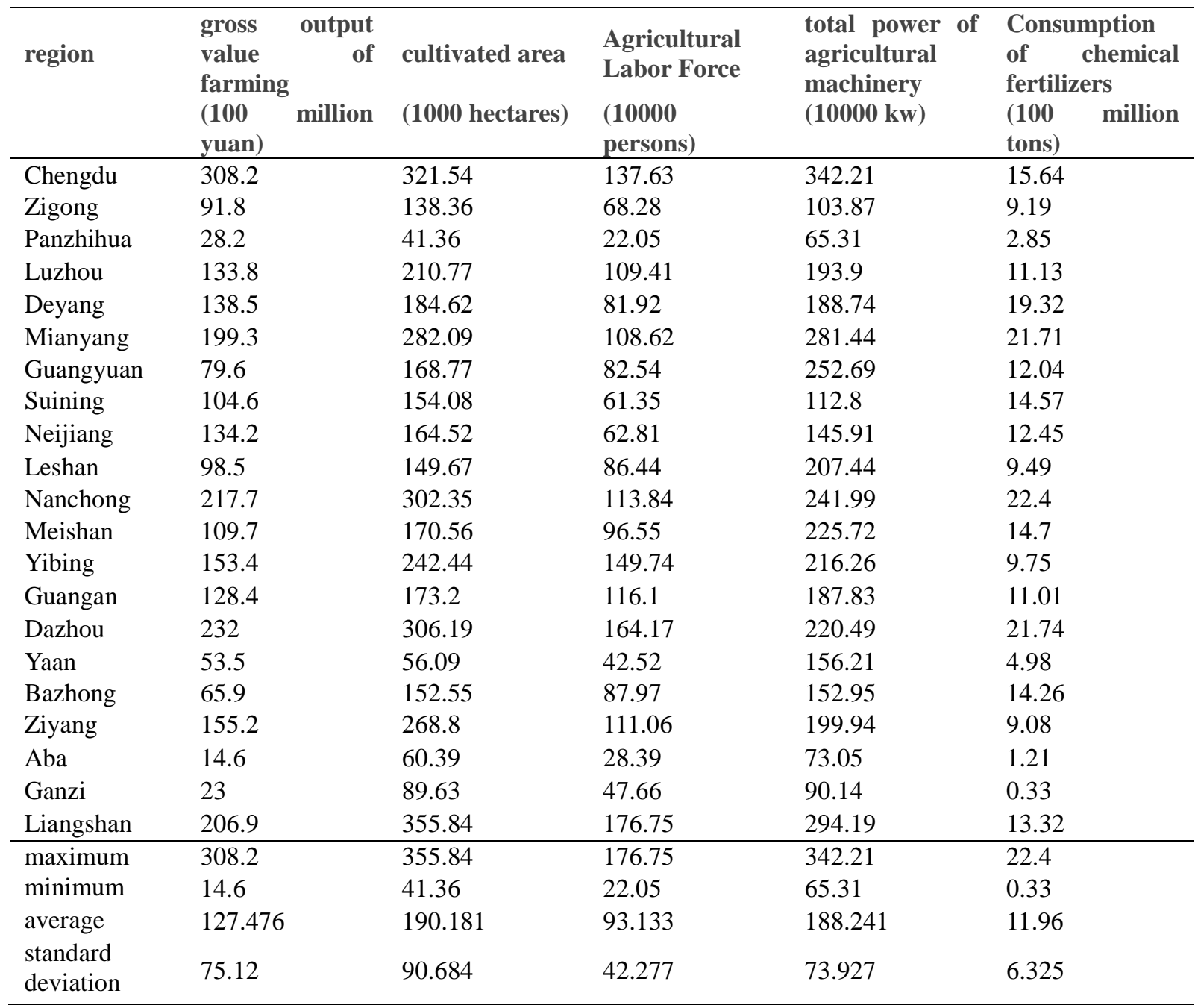

The original data came from Statistical Yearbook of Sichuan Province

\subsection{Model Estimation Results}

Take logarithm on both sides of the CD function form of production function

$\mathrm{Y}=\mathrm{AX}_{1}{ }^{\beta 1} \mathrm{X}_{2}{ }^{\beta 2} \mathrm{X}_{3}{ }^{\beta 3} \mathrm{X}_{4}{ }^{\beta 4}$, can be turned into linear function, make regression can get:

$$
\begin{array}{lccccc}
\ln Y=0.625 \times \ln \left(X_{1}\right)+ & 0.069 \times \ln \left(X_{2}\right)+0.221 \times \ln \left(X_{3}\right)+0.304 \times \ln \left(X_{4}\right)-0.691 \\
\mathrm{t} & (2.0281) & (0.1914) & (0.8138) & (3.6926) & (-0.8092) \\
\text { Prob. } & \left(0.0595^{*}\right) & (0.8506) & (0.4277) & \left(0.0020^{* * *}\right) & (0.4302)
\end{array}
$$

$\mathrm{R}^{2}=0.9179 \quad$ AdjustedR ${ }^{2}=0.8974 \quad \mathrm{~F}=44.7757$

It can be seen that determination coefficient and adjusted coefficient is greater than 0.8 , and the model's goodness-of-fit is good. F statistic is of 44.7757, check the degree of freedom for $(4,16)$ in the $F$ distribution table, at 5\% significance level, get the critical value $\mathrm{F} 0.05(4,16)=3.01$, at $1 \%$ significance level, get the critical value for $\mathrm{F} 0.01(4,16)=4.77$, because $\mathrm{F}=$ $44.7757>4.47$, so the model is significant as a whole. farmland acreage $\mathrm{X}_{1}$ is significant at $10 \%$ level and close to $5 \%$ significant level, fertilizer usage amount $\mathrm{X}_{4}$ significant at $1 \%$ level, due to the nature of the logarithm linear model, its coefficient measured the elasticity of explanatory variable $\mathrm{Xi}$ on explained variable $\mathrm{Y}$, namely the elasticity of farmland acreage on agricultural output is about 0.6253 , means every one percent increase of farmland acreage, agricultural output will be increased by $0.6253 \%$. The elasticity of fertilizer usage amount on agricultural output is 0.3049 , every one percent increase of fertilizer usage amount, agricultural output would increase by $0.3049 \%$.

The significance of agricultural labor force and the total power of agricultural machinery are not obvious, 
the reason is that the actual input of agricultural production is the effective agricultural labor time, and the time is hard to measure, so use agricultural labor force to replace the agricultural labor time in the model. On the one hand, lots of agricultural labor force had by-business, engaged in agricultural labor and engaged in second or third industry when they migrated to cities on the other hand, if only engaged in agricultural labor, there are difference between slack farming season and busy farming season, difficult to measure the actual labor time. Thus eliminate agricultural labor force to adjust the original model, got:

$$
\begin{array}{lcccc}
\ln Y=0.672 \times \ln \left(X_{1}\right)+0.245 \times \ln \left(X_{3}\right)+0.303 \times \ln \left(X_{4}\right)-0.747 \\
\mathrm{t} & (3.7880) & (1.0481) & (3.8052) & (-0.9580) \\
\text { Prob. } & \left(0.0015^{* * *}\right) & (0.3093) & (0.0014 * * *) & (0.3515)
\end{array}
$$

\section{$\mathrm{R} 2=0.9178 \quad$ AdjustedR2 $=0.9032 \quad \mathrm{~F}=63.2743$}

It can be seen that determination coefficient and adjusted coefficient is greater than 0.9 , suggests that goodness of fit is also improved. F statistic value is of 63.2474 , check the degree of freedom for $(3,17)$ in the $F$ distribution table, at $5 \%$ significance level, get the critical value for $\mathrm{F} 0.05(3,17)=3.20$, at $1 \%$ significance level, get the critical value for $\mathrm{F} 0.01(3,17)=5.18$, because $F=63.2747>5.18$, so the model is significant as a whole. At the same time, farmland acreage $X_{1}$ is significant at $1 \%$ level, fertilizer usage amount $\mathrm{X}_{4}$ significant at $1 \%$ level. While the second model is more significant after eliminating the variable of the agricultural labor force, but on the one hand the original Cobb-Douglas function contains labor force, on the other hand even agricultural machinery are needed to operate by labor force, so the first model still has the rationality, according to the principle of first consider the economic meaning secondly considering statistical test, the two models coefficient of farmland acreage variable $\ln \mathrm{X}_{1}$ is equal to 0.6491 on average, as the elasticity of farmland acreage on agricultural output.

According to the principle of optimization under the condition of equilibrium, that is, the marginal benefit equals marginal cost, get:

$$
\frac{\partial Y}{P_{s} \partial X_{1}}=1
$$

Among them, the numerator of the left equation means each additional unit production factors increased bring about the increment of agricultural output, namely marginal revenue, the Ps of the denominator is for farmland shadow price (price under the condition of optimal resource allocation), the $\mathrm{X}_{1}$ is increments of the farmland, and Multiplied by farmland shadow price is the marginal cost. $\mathrm{LnX}_{1}$ coefficient is of 0.6491 , the elasticity of farmland acreage on agricultural output is 0.6491 . Elasticity can be written as:

$$
e=\frac{d Y}{d X_{1}} \bullet \frac{X_{1}}{Y}=0.6491
$$

The shadow price of farmland $\mathrm{PS}=\beta 1 \mathrm{Y} / \mathrm{X}_{1}=0.6491 \mathrm{Y} / \mathrm{X}_{1}, \mathrm{Y}$ use the average of the agricultural output in 21 cities, the $\mathrm{X}_{1}$ use the average of the farmland acreage in 21 cities, can get the farmland shadow price is $43508.238 \mathrm{Yuan} / \mathrm{hm}^{2}$, one hectare equals $15 \mathrm{Mu}$ in conversion, is $2900.5492 \mathrm{Yuan} / \mathrm{Mu}$.

\subsection{The Discussion of the Results}

Yingqi Zhang, and Yiding Yue (2010) in the study of farmland finance from differentiation perspective, used data of eight provinces such as Hunan, Hubei, Shanxi, Jiangxi etc, adopted the productivity quantitative model and calculated the shadow price of farmland was 29547.15Yuan/hm2(1969.81 Yuan/Mu) in 2008. And in study of this paper the farmland shadow price is of Sichuan province in 2013. Among five years within 2008-2013, happened the global financial crisis, in order to cope with the crisis, our country had taken a positive monetary policy, so considered monetary inflation, we used the consumer price index (CPI) for conversion. According to the China statistical yearbook, selected foods in the consumer price index for conversion, because agricultural production mainly to meet people's food demand. The national food consumer price index from 2009 to 2013, previous year as a benchmark, respectively is $100.7 ; 107.2 ; 111.8 ; 104.8 ; 104.7$, according to Yingqi Zhang (2010) the farmland shadow price in 2008 was 29547.15Yuan/hm2(1969.81 Yuan/Mu), considered inflation and adjusted by CPI, after conversion to 2013 the farmland shadow price was of 39128.18 Yuan $/ \mathrm{hm}^{2}$ (2608.5452 Yuan/Mu). Which was relatively close to the study of this paper, the farmland shadow price of Sichuan province was of 43508.238Yuan $/ \mathrm{hm} 2$ $(2900.5492$ Yuan/Mu) in 2013, all in $39000-44000$ Yuan $/ \mathrm{hm}^{2}$ price range.

The farmland undervalue, can produce a series of impact on farmland finance. According to the survey of 2013, the average farmland acreage of every peasant household was of $3.656 \mathrm{Mu}$, every peasant household had 5.12 plots farmland on average, and $0.71 \mathrm{Mu}$ per plots on average. This phenomenon shows that there is a certain degree of farmland fragmentation under the household contract responsibility system. We used the average of the survey as standard, to consider a typical peasant household, the peasant household to apply for farmland management rights mortgage loan to the bank, so the bank would face a transaction client with small farmland acreage $(3.656 \mathrm{Mu})$, fragmentation plots (5 plots and 0.7 Mu / plots). 
If, in accordance with the reality of farmland transfer price (971.02 Yuan/Mu) to estimate the mortgaged property, calculated at an annual interest rate of $3 \%$ in 2013, and five years, the valuation of mortgaged property farmland management rights was of 4446.98 Yuan, mortgage rates as $60 \%$, the bank would loan out 2668.18 Yuan. Loan interest rate was calculated according to $6.4 \%$, the interest income of the bank would be 170.76 Yuan when the peasant household execute it's promises, the deposit cost which the bank paid was 80.04 Yuan, to assume contract transaction costs of the bank was 50 Yuan, the bank's profits (interest income minus monetary cost and transaction cost) was 40.72 Yuan, at this point, the bank's cost-profit ratio or return on investment(ROI) was of $31.3 \%$.

If estimate the value of collateral according to the farmland shadow price (2900.5492 Yuan/Mu), transaction costs still 50 Yuan, because at this time confronted the same peasant household and the same farmland, calculated at an annual interest rate of $3 \%$ in 2013, and five years, the valuation of mortgaged property farmland management rights was of 13283.6452 Yuan, mortgage rates as $60 \%$, the bank would loan out 7970.18 Yuan. Loan interest rate was calculated according to $6.4 \%$, the interest income of the bank would be 510.09 Yuan when the peasant household execute it's promises, the deposit cost which the bank paid was 239.10 Yuan, the bank's profits (interest income minus monetary cost and transaction cost) was 220.99 Yuan, at this point, the bank's cost-profit ratio or return on investment(ROI) was of $76.4 \%$.

Confronted with the same peasant household and farmland, the bank's profit margin was $31.3 \%$ when the value of the collateral was low. When collateral value was high, banks' margin was $76.4 \%$. Because of the horizontal comparability of profit margins (or ROI), it is the basis for banks to choose investment objects and investment opportunities. Comparatively low collateral valuations brought about thinner profits and profit margins, made banks reluctant to loan for peasant household (more inclined to agricultural enterprises or large-scale owner), and some scholars even thought that peasant household financing through farmland finance "had idealism color". However, if let the market play a bigger role in the allocation of resources, the farmland, as a production factor, be evaluated as shadow price under the condition of optimal resources allocation, the bank's cost-profit ratio can reach $76.4 \%$, the bank as a rational entity, at the higher profit margins will naturally tend to provide loans to peasant household, in turn, it increases the availability of funds for peasant household, more conducive to promote the development of farmland finance.

\section{FARMLAND FINANCIAL POLICIES OF OTHER COUNTRIES}

In 1770, Prussia formed the first land mortgage credit cooperation. Germany farmland financial system was build upon the base of land property right ownership legislation and mortgage legislation, manifested the obvious characteristics of constructing from bottom to top. The grassroots of the German farmland finance organization is the land mortgage credit cooperative, the land mortgage credit cooperatives upward developed and established the joint cooperative bank. The main business of the joint cooperative bank is to sale bonds, interest payments and repo bonds as broker of cooperation, and to provide financing for them. The main source of funds for the German farmland financial system is the issuance of bonds, the land in various regions jointed as collateral to bear the issuance.

The development of agriculture in South Africa is similar to that of China today, the development of agricultural is lagging behind industry and commerce. In order to solve the problem of urban and rural dilemma, especially to eliminate racial discrimination in agricultural production, and to increase funding for agriculture, the land bank was established in 1912. Main sources of funds for the South African land bank was bond financing, Major loan products included general land mortgages, special mortgages, micro-credit etc, special mortgages loan aimed to help social vulnerable groups.

The early development policy of farmland finance about the above countries shows that, clarify farmland property right relationship, cultivate farmland market is the foundation of establishing farmland finance. Clear farmland property right relation is the premise of system construction, and the transfer of farmland management right is the core of system operation, both of which are indispensable to the construction of farmland finance. The past of China farmland property right ownership was not clear, which lead to the imperfect of farmland market, not conducive to the formation of the farmland market prices, the assessment of farmland management right as collateral also lack of scientific basis, composed a serious obstacle to establish the farmland financial system. Therefore, to divide the land management right out in the "Three kinds of rights Separation", makes the farmland to transfer in a larger scope, farmland market also gradually improve, helpful to the Chinese farmland financial system establishment and efficient operation.

\section{POLICY IMPLICATION}

The concept of "80-20 rule" is deeply ingrained in banks operation philosophy and traditionally under the influence of it for a long time, namely $20 \%$ customers create $80 \%$ profits, financial resources more inclined to 
"head", 20\% of high school end customers (such as a large agricultural enterprises, large-scale business owners of land, etc.),financial resources more inclined to focus on the middle or high-end customers which occupy the $20 \%$ "head" (such as a large agricultural enterprises, etc.), and for $80 \%$ of the peasant households, small and micro businesses which occupy the "tail", especially the peasants due to lack of effective collateral, single loan amount is small, high transaction cost, makes it difficult for banks to exert scale effect, operating costs is also high. In order to reduce operating costs and increase profits, Banks have incentive to "despise the poor and curry favor with the rich ", and do not want to provide basic financial services to peasants, exist the phenomenon of financial exclusion.

In 2005, the United Nations proposed the idea of financial inclusion, a financial system that provides services to all social classes and groups, effectively and comprehensively. At present, in China "all social classes and groups", the financial services for peasants was most needed to be strengthened, especially peasants lived in poor areas, in order to solve their loan difficulty problems. The idea of financial inclusion is encourage financial innovation, especially the innovation of financial products and financial services. Farmland management rights mortgage financing, as well as other rural assets rights mortgage practices, is beneficial to solve the loan difficulty problem of poor peasants, farmland is the most widely and most common form of property belong to peasants, the development of farmland finance is an important practice and realization form of financial inclusion.

As mentioned above, to use shadow price of farmland as reference price, to assess the collateral value of farmland management right, It could increase the loan amount of peasants and the profitability of banks, reverse the "80-20 rule" idea traditionally hold by banks, Make banks willing to grant a loan to peasants, increase the peasants' accessibility to credit, protect peasants' interests and give consideration to the interests of banks at the same time, fulfill the idea of financial inclusion. In the process, it is important to accelerate the construction of the farmland management right market, and to regulate the way farmland value is evaluated.

\section{CONCLUSION}

The Research results shows that the shadow price of farmland in Sichuan province was 43508.238 Yuan $/ \mathrm{hm} 2$, as collateral valuation reference prices. Research conclusion: to use the farmland shadow price as a reference to estimate the mortgaged property, can increase bank margins and increase the availability of funds for peasant household, is conducive to the development of farmland finance.

\section{REFERENCES}

[1] Gershon Feder and David Feeny(1991), Land Tenure and Property Rights: Theory and Implications for Development Policy[J], The World bank economic review, VOL 5 No 1.

[2] Huang na, (2015) The research review and prospect of the "three kind of rights separation" of farmland property rights $[\mathrm{J}]$ Rural Economy and science technology, 08.

[3] Han Changfu, (2016) The land "three rights separation" is another major innovation in rural reform in China [J] Rural work message, 03.

[4] Wang xuanqing, Wang leirong, (1999) Quantitative Analysis Of The Agricultural Productive Force-Estimating the Shadow Price of Farm Products by the Model of Quantitative Analysis of the Agricultural Productive Force[J], Journal of China Agricultural Resources and Regional Planning, 05.

[5] Yingqi Zhang, (2010) A Research on the Operational Mechanism of Rural Land Finance from the Perspective of differentiation Strategy [D] Central South University.

[6] YANG Zhenyu, ZHANG Rixin(), A Study of Influencing Factors on Rural Land Lease Prices from the Perspective of Spatial Heterogeneity[J]. Economic Survey, 2020 Vol37, No.2.

[7] Wuxuebing, Dingjianjun, Hepuiming, Study on the formation logic of farmland transfer price deviation and its influence on food security[J]. World Agricultural, 2020,11.

[8] HUANG Wenbin, CHEN Fengbo, TAN Ying, The effect of grain production purpose on the disparity of farmers' land transferring willingness price[J]. Resources Science,2017, Vol.39, No.10 Oct. 